\title{
Advanced glycation End-products (AGEs): an emerging concern for processed food industries
}

\author{
Chetan Sharma $^{1} \cdot$ Amarjeet Kaur $^{1} \cdot$ S S Thind ${ }^{1} \cdot$ Baljit Singh $^{1} \cdot$ Shiveta Raina $^{2}$
}

Revised: 12 April 2015 / Accepted: 22 April 2015 / Published online: 1 August 2015

(C) Association of Food Scientists \& Technologists (India) 2015

\begin{abstract}
The global food industry is expected to increase more than US $\$ 7$ trillion by 2014. This rise in processed food sector shows that more and more people are diverging towards modern processed foods. As modern diets are largely heat processed, they are more prone to contain high levels of advanced glycation end products (AGEs). AGEs are a group of complex and heterogeneous compounds which are known as brown and fluorescent cross-linking substances such as pentosidine, non-fluorescent cross-linking products such as methylglyoxal-lysine dimers (MOLD), or non-fluorescent, non-cross linking adducts such as carboxymethyllysine (CML) and pyrraline (a pyrrole aldehyde). The chemistry of the AGEs formation, absorption and bioavailability and their patho-biochemistry particularly in relation to different complications like diabetes and ageing discussed. The concept of AGEs receptor - RAGE is mentioned. AGEs contribute to a variety of microvascular and macrovascular complications through the formation of cross-links between molecules in the basement membrane of the extracellular matrix and by engaging the receptor for advanced glycation end products (RAGE). Different methods of detection and quantification along with types of agents used for the treatment of AGEs are reviewed. Generally, ELISA or LC-MS methods are used for analysis of foods and body fluids, however lack of universally established method highlighted. The inhibitory effect of bioactive components on AGEs by trapping variety of
\end{abstract}

Amarjeet Kaur

amarak1234@rediffmail.com

1 Department of Food Science and Technology, Punjab Agricultural University, Ludhiana, India

2 Department of Microbiology, Punjab Agricultural University, Ludhiana, India chemical moieties discussed. The emerging evidence about the adverse effects of AGEs makes it necessary to investigate the different therapies to inhibit AGEs.

Keywords Advanced glycation end-products (AGEs) . Processed foods $\cdot$ Microvascular complications . Macrovascular complications · Anti-AGE therapies

\section{Introduction}

Advanced glycation end-products (AGEs) were first identified in cooked food as end-products from a non enzymatic reaction between sugars and proteins called the Maillard reaction (Cordain et al. 2005). The Maillard reaction (non enzymatic glycation or browning) in foods has been well studied by the food industry to control food quality. However, it is only 40 years ago that a similar glycation process was recognized in human body by the observation of increased formation of glycosylated haemoglobins in diabetic patients (Rahbar et al. 1969) and this would lead to the formation of detrimental advanced glycation endproducts (AGEs) in humans. AGEs are a group of complex and heterogeneous compounds which are known as brown and fluorescent cross-linking substances such as pentosidine, non-fluorescent cross-linking products such as methylglyoxal-lysine dimers (MOLD), or non-fluorescent, non-cross linking adducts such as carboxymethyllysine (CML) and pyrraline (a pyrrole aldehyde) (Ikeda et al. 1996; Rahbar and Figarola 2002). Advanced Glycation end-products are formed by reducing sugars non-enzymatically with the amino groups of proteins to initiate a complex series of rearrangements and dehydration to produce a class of irreversibly cross-linked and fluorescent moieties (Kume et al. 2005). 
The body also produces AGEs naturally as it processes sugars. The formation of AGEs is a part of normal metabolism, but if excessively high levels of AGEs are reached in tissues and the circulation they can become pathogenic (Ulrich and Cerami 2001). The pathologic effects of AGEs are related to their ability to promote oxidative stress and inflammation by binding with cell surface receptors or cross-linking with body proteins, altering their structure and function (Uribarri et al. 2010). The formation and accumulation of AGEs is a characteristic feature of tissues in aged people, especially in patients with diabetes mellitus, and these products have also been strongly implicated in the pathogenesis of age-related and diabetic complications. Many chronic diseases, including heart diseases, diabetes and both osteoarthritis and rheumatoid arthritis are associated with inflammation. It has been reported that AGEs are involved in musculoskeletal diseases such as osteoarthritis (OA), which is the most common chronic disabling disorder for aged people. Accumulation of AGEs in the articular cartilage in OA patients biochemically affects cellular characteristics and increases stiffness and brittleness of the tissue (Verzijl et al. 2003). Accumulation of AGEs increases stiffness of the collagen network in the bone as well, which may explain some of the age-related increase in skeletal fragility and fracture risk (Vashishth et al. 2001). AGEs can be particularly dangerous for diabetics, as the increased availability of glucose in diabetes patients accelerates the formation of AGEs. Apart from their presence in a wide variety of body tissues, AGE have also been identified from exogeously derived sources such as tobacco (Nicholl and Bucala 1998) and certain foods, particularly those that are heated (O'Brien and Morrissey 1989).

The study of AGE represents one of the most promising areas of research today. Although the initial chemistry behind their formation has been known since the early 1900s, it is only in the last 20 years or so that important work has been done to elaborate on this. The chemical processes and pathways that ultimately lead to AGE formation have, however, yet to be fully clarified (John and Lamb 1993). As our knowledge of AGE chemistry increases it is becoming apparent that not all AGE have been isolated, whereas as those that have been characterized are both complex and heterogenous. Thus, the discovery and investigation of AGE inhibitors would offer a potential therapeutic approach for the prevention of diabetic or other pathogenic complications.

\section{In vitro and in vivo chemistry of AGEs}

AGEs can be formed from a variety of precursors for the Maillard reaction. The formation of AGE is usually endogenous but can be derived from exogenous sources such as tobacco smoke or food (Nicholl and Bucala 1998; O’Brien and Morrissey 1989; Cerami et al. 1997). Thermal processing is an important part of modern food preparation that can increase palatability, prolong shelf-life, and reduce food-borne diseases. Many commercially processed foods such as dry mixes or canned soups, which often contain larger amounts of protein and carbohydrates, undergo Maillard reaction during heat-processing and they continue to brown during storage.

AGEs are products of the Maillard reaction, which is initiated by the non - enzymatic reaction between a carbonyl compound and an amine group (Fig. 1). Generally, there are three stages in the non enzymatic glycation process in vivo. First, glycation is initiated by the covalent attachment of reducing sugars to amino groups of proteins, lipids, or nucleic acids to produce reversible and an unstable Schiff base. Then, the Schiff base may undergo Amadori rearrangement and change to a more stable Amadori product. Subsequently, Amadori products undergo dehydration and rearrangement to form highly reactive carbonyl species (RCS) including 3deoxyglucosone (3-DG), glyoxal (GO) and methylglyoxal (MGO). These compounds are known as dicarbonyls or oxoaldehydes and include such products as 3-deoyglucosone (3-DG) and methylglyoxal (MGO) (Skovsted et al. 1998). The 3-DG is formed by non-oxidative rearrangement and hydrolysis of Amadori adducts (Baynes and Thorpe 1999) and from fructose-3-phosphate which is a product of the polyol pathway. MGO is also formed from non-oxidative mechanisms in anaerobic glycolysis (Thornalley 1996) and from oxidative decomposition of polyunsaturated fatty acids (PUFA) (Thornalley et al. 1995). Finally, reactions between these reactive carbonyls and amino, sulphydryl and guanidine functional groups of intracellular and extracellular proteins (Frye et al. 1998) would result in the formation of AGEs (Peng et al. 2008a).

If oxidation accompanies glycation then the products formed are known as glyco-oxidation products. The AGE pentosidine, methyl glyoxal lysine dimer (MOLD) and $N^{E}$ [carboxymethyl]-lysine (CML) are such examples (Fig. 2). A great variety of compounds with different composition and molecular weight can be included into the food-derived AGEs, due to the presence of a large variety of AGE precursors, including reducing sugars, amino acids and peptides with free amino groups, as well as non-protein-bound amino groups (Poulsen et al. 2013). Of importance in the Maillard reaction is the formation of reactive intermediate products during Amadori rearrangement. Reactive carbonyl species produced through sugar autoxidation, lipid per-oxidation and UV-photo damage may also contribute to the formation of AGEs. The accumulation of reactive di-carbonyl precursors or of glycoxidation or both and lipoxidation products is termed carbonyl stress (Miyata et al. 1999; Suzuki et al. 1999). This recently described phenomenon of carbonyl stress has been observed in both diabetes and uraemia and has been implicated in the accelerated vascular damage observed in both conditions (Raj et al. 2000). 
Fig. 1 Advanced glycation end-products (AGE) formation including initial intermediates products

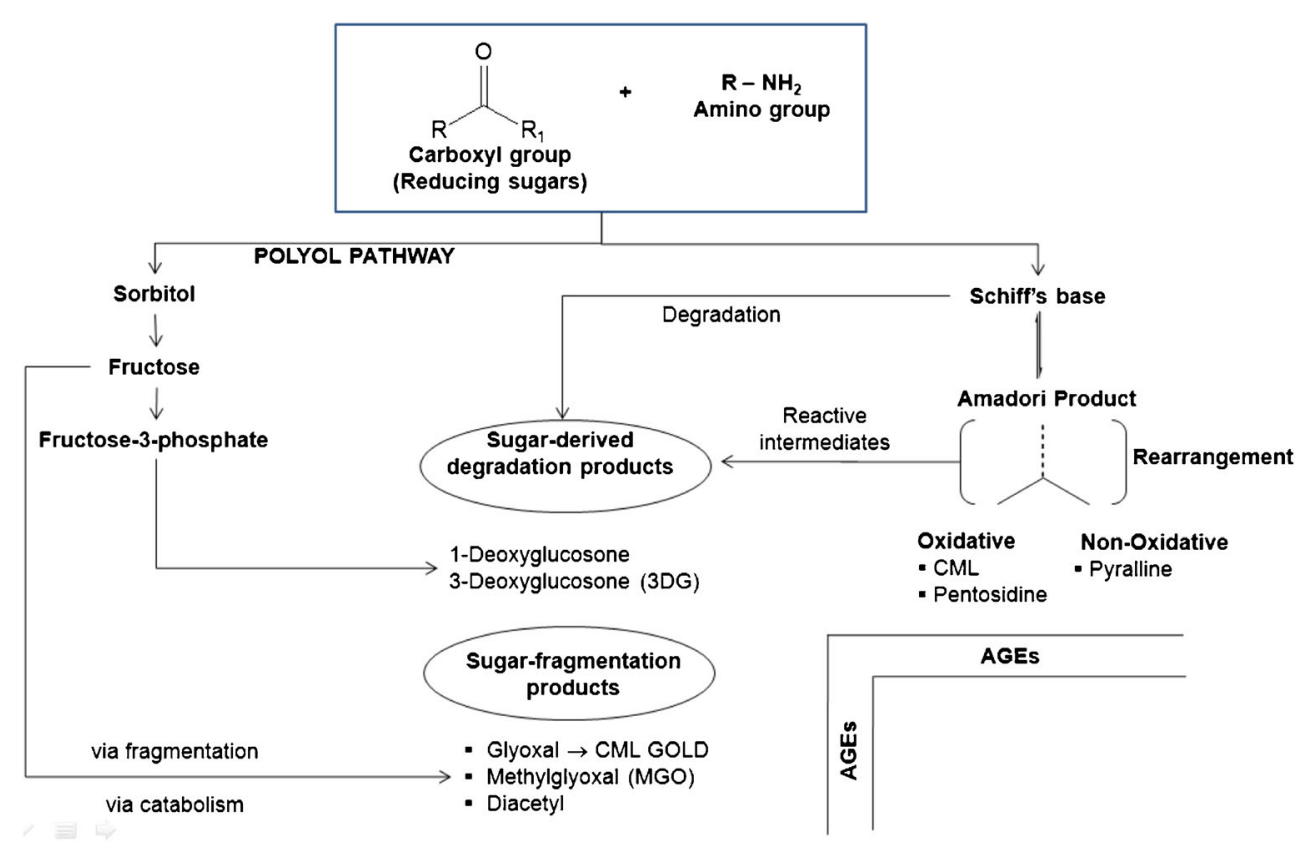

Endogenously, the formation of AGEs occurs in all tissues and body fluids under physiological conditions through glycation reactions (Ahmed et al. 2005a). AGEs are formed physiologically at lower temperatures than in food, and therefore a lower diversity of compounds is found. Endogenous glycation was demonstrated for the first time with the identification of the hemoglobin variant $\mathrm{HbA}_{1 \mathrm{c}}$, in which the Nterminal valine residue reacted with glucose to form $\mathrm{N}-\mathrm{a}-$ fructosylvaline (Rahbar et al. 1969). Physiologically formed AGEs are defined as the non-enzymatic reaction of glucose, aoxoaldehydes, and other saccharide derivatives, with proteins, nucleotides, and lipids, in the human body (Thornalley, 1999). Glucose has the slowest glycation rate, whereas intracellular sugars, such as glucose-6-phosphate and fructose, form AGE at a faster rate (Bierhaus et al. 1998a). Four types of processes have been identified in the formation of AGEs under physiological conditions (Ahmed et al. 2002): (i) monosaccharide autoxidation (autoxidative glycosylation) or the degradation of saccharides unattached to a protein, (ii) Schiff's base fragmentation, (iii) fructosamine degradation, and (iv) $\alpha, \beta-$ dicarbonyl compounds formed from the degradation of glycolytic intermediates and lipid peroxidation.

Advanced glycation occurs over a period of weeks, thereby affecting long-lived proteins. Structural components of the connective tissue matrix or basement membrane, such as
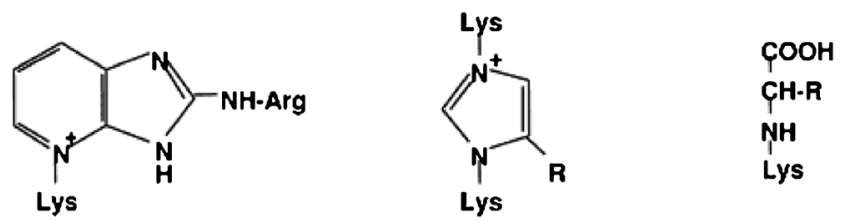

Fig. 2 Structure of the AGE Pentosidine, MOLD and CML collagen, are prime targets but can also include myelin, complement $\mathrm{C} 3$, tabulin, plasminogen, activator and fibrinogen. In uraemia, however, which is associated with very high concentrations of AGE accumulation, even shorter lived compounds such as lipid constituents and nucleic acids are affected (Vlassara and Bucala 1996).

\section{Toxicity of advanced glycation end-products (AGEs)}

The possible pathophysiological role of AGEs has become a topic of increasing interest over the past few years. With the continued research on the Maillard reaction, it was demonstrated that the Maillard reaction also occurs in vivo and the term "glycation" was introduced as a synonym for "non-enzymatic glycosilation", in order to distinguish this from the well known enzymatic glycosilation of proteins (Brownlee et al. 1984). Protein modifications called "Advanced glycation end-products (AGEs)", which are formed during aging, diabetes and in renal failure via comparable chemical pathways as described for heated foods, nowadays are generally accepted to play a pivotal pathophysiological role in several diseases (Table 1.) (Raj et al. 2000). In vitro studies using humanderived endothelial cells exhibited the food-derived AGEs have same protein cross-linking and intracellular oxidant stress actions as their endogenous counterparts. In animal studies like in mice, reduction of dietary AGE intake is accompanied by significant reduction of circulating AGEs levels as well as reduction of diseases related to inflammation and oxidative stress. A low-AGE diet has been associated with a significant increase in mouse lifespan. The human relevance of the in vitro and animal data discussed in a number of studies 
Table 1 Advanced glycation end-products (AGEs): At a Glance

Advanced glycation endproducts (AGEs)

Dietary intake of AGEs

Mitigation in food

Toxicity of AGEs

Medications
•Protein modifications such as altering their structure and function called "Advanced glycation end-products"

-Depends on the thermal treatment of food incurred

-Amount varies even within the same type of food

-Glycation reactions are responsible for desired flavour, colour etc. Thus, considerable attention must be paid to the beneficial aspects of the Maillard reaction.

-Promote oxidative stress and inflammation related diseases like atherosclerosis, diabetes, acute vascular injury and chronic kidney disease

-Associated with age-related and diabetic complications like cataract, joint stiffening

-Increased stiffness of the collagen network in the bone, resulted in increase in skeletal fragility and fracture risk

-Accumulation of glycation compounds in the plasma and tissues represent an important class of "uremic toxins"

-AGEs and RAGE can profoundly be involved in cardiovascular diseases through regulation of atherogenesis, angiogenic response, vascular injury and inflammatory response

-Intake of antioxidant rich diets like vitamin $\mathrm{E}$, vitamin $\mathrm{C}$, alpha lipoic acid, taurine etc.

-Agents like aminoguanidine, metformin, benfotiamine and pyridoxamine can prevent AGEs formation.

-Use of AGEs crosslink breakers like ALT 711 or alagebrium drug

-Lower cooking temperature

-Addition of acids (vinegar, lemon juice) lowers AGEs level found independent correlate of the circulating AGEs with the dietary AGEs intake. Moreover, the effect of a low and a highAGE diet on the inflammatory mediators was also studied by using a group of diabetic subjects. The low-AGE diet significantly reduced serum AGE levels as well as markers of inflammation and endothelial dysfunction. Thus, all these studies demonstrate the associated toxicity of AGEs (Uribarri 2012).

\section{Dietary advanced glycation end-products (d-AGEs)}

A large database of different food items and their AGE contents has been created by measuring CML with ELISA (Goldberg et al. 2004; Uribarri et al. 2010). In general the reported CML contents are correlated with corresponding levels of MG-derivatives (Uribarri et al. 2010). AGE content of foods as determined by CML and MG levels shows a highly significant linear correlation $(\mathrm{r}=0.8, P=0.0001)$ prepared by different cooking techniques. The highly significant internal correlation between two chemically distinct AGEs (CML and $\mathrm{MG}$ ) in a variety of foods prepared by different methods validates the methodology applied and supports the choice of CML levels as a useful marker of d-AGE content.

As with CML, foods high in protein and fat contained higher amounts of MG than did carbohydrate-rich foods. Recent studies indicate that the meat group contains the highest levels of AGEs because meats are served in larger portions as compared to fats which tend to contain more dAGE per gram of weight. When items in the meat category prepared by similar methods were compared, the highest dAGE levels were observed in beef and cheeses followed by poultry, pork, fish, and eggs. Lamb ranked relatively low in dAGEs compared to other meats.

Higher-fat and aged cheeses, such as full-fat American and Parmesan, contained more dAGEs than lower-fat cheeses, such as reduced-fat mozzarella, $2 \%$ milk cheddar, and cottage cheese. Whereas cooking is known to drive the generation of new AGEs in foods, it is interesting to note that even uncooked, animal-derived foods such as cheeses can contain large amounts of dAGEs. This is likely due to pasteurization and/or holding times at ambient room temperatures (e.g., as in curing or aging processes). Glycation-oxidation reactions, although at a slower rate, continue to occur over time even at cool temperatures, resulting in large accumulation of dAGEs in the long term. High-fat spreads, including butter, cream cheese, margarine, and mayonnaise, was also among the foods highest in dAGEs, followed by oils and nuts. As with certain cheeses, butter and different types of oils are AGE-rich, even in their uncooked forms. This may be due to various extraction and purification procedures involving heat, in combination with air and dry conditions, however mild they are. The type of cooking fat used for cooking led to the production of different amounts of dAGEs.

In comparison to the meat and fat groups, the carbohydrate group generally contained lower amounts of AGEs due to the higher water content or higher level of antioxidants and vitamins in these foods, which may diminish new AGE formation. The highest dAGE level per gram of food in this category was found in dry-heat processed foods such as crackers, chips, and cookies. This is likely due to the addition of ingredients such as butter, oil, cheese, eggs, and nuts, which during dry-heat processing substantially accelerate dAGE generation. Although AGEs in these snack types of food remain far below those present in meats, they may represent an important health 
hazard for people who consume multiple snacks during the day or as fast meals (Story et al. 1996).

Grains, legumes, breads, vegetables, fruits, and milk were among the lowest items in dAGE, unless prepared with added fats. For instance, biscuits had more than 10 times the amount of dAGEs found in low-fat breads, rolls, or bagels (Uribarri et al. 2010).

Nonfat milk had significantly lower dAGEs than whole milk. Whereas heating increased the dAGE content of milk, the values were modest and remained low relative to those of cheeses. Likewise, milk-related products with a high moisture index such as yogurt, pudding, and ice cream were also relatively low in AGEs (Uribarri et al. 2010).

\section{Factors affecting the rate of dietary AGEs (d-AGEs) formation during cooking}

The rate of formation and the diversity of the generated AGEs in food depend on factors such as composition, availability of precursors, presence of transition metals, and availability of pro- and antioxidants. Reaction time, processing temperature, concentrations of reactants, availability of water, and $\mathrm{pH}$ are particularly well known to have a decisive effect on the rate of the Maillard reaction (Vlassara and Uribarri 2004). As a rule of thumb, the rate of the Maillard reaction at least doubles when the temperature is increased by $10{ }^{\circ} \mathrm{C}$. If browning is used to measure the progress of the Maillard reaction, then four weeks at $20^{\circ} \mathrm{C}, 3 \mathrm{~h}$ at $100{ }^{\circ} \mathrm{C}$, and $5 \mathrm{~min}$ at $150{ }^{\circ} \mathrm{C}$ give approximately the same result (Ledl and Schleicher 1990). Factors like $\mathrm{pH}$ (Nursten 2005a, b) and water activity greatly affect the rate of formation of Maillard reaction products (MRPs).

The rate of the Maillard reaction is considered to be low at acidic $\mathrm{pH}$, but increases with increasing $\mathrm{pH}$ until a maximum is reached around $\mathrm{pH} 10$ (O'Brien and Morrissey 1989). At higher moisture levels, a decrease in reaction rate is observed due to dilution of the reactants in the aqueous phase. Water is a product of the reaction and it is probable that the law of mass action also leads to a decreased rate of reaction at high moisture levels (Poulsen et al. 2013). Dry heat cooking has been found to promote formation of dietary AGEs as determined by immunological methods. However, AGE formation seems to be reduced by heating in an oven at high humidity, shorter cooking times, lower cooking temperatures, or by the use of acidic ingredients, such as lemon juice or vinegar.

\section{Absorption and bioavailability}

Early animal studies reported that MRPs are at least partially absorbed, and those low molecular weights (LMW) MRPs are absorbed to a higher degree than high molecular weight
(HMW) MRPs (Finot and Magnenat 1981). The absorption of AGEs into the circulation in humans measured by a nonspecific ELISA method was estimated to be about $10 \%$ of ingested AGEs (Koschinsky et al. 1997). HMW AGEs need to be degraded by gut proteases before the LMW products are liberated. The bioavailability of the partially degraded HMW AGEs will depend on the size of the associated peptide, type of diet, gut environment, and duration of their presence in the gut. Heat-induced changes in proteins can decrease their susceptibility to degradation by gastrointestinal enzymes, and protein and mineral bioavailability have been shown to be influenced negatively by a heat-treated diet (DelgadoAndrade et al. 2011; Garcia et al. 2009; Seiquer et al. 2006). Oral bioavailability is thought to be low $(10 \%)$, secondary to poor absorption from the gastrointestinal tract, as AGE cross link formation is resistant to enzymatic or chemical hydrolysis (Koschinsky et al. 1997). The water solubility and amphoteric properties makes LMW AGEs to be absorbed to extracellular and intracellular compartments than HMW AGEs.

The in vivo distribution of CML and CEL after an intravenous injection in rats showed a temporary accumulation in the liver (Bergmann et al. 2001), indicating that they may have high affinity to some specific hepatic proteins. In the study of ${ }^{14} \mathrm{C}$ labeled AGEs, it was observed that $60 \%$ of the absorbed AGEs were bound in liver and kidney after $72 \mathrm{~h}$, but radioactivity was also observed in lung, heart, and spleen indicating more global distribution and tissue binding (He et al. 1999). Several animal studies have shown a correspondence between dietary AGE content and serum and tissue AGE levels (Peppa et al. 2003a; Hofmann et al. 2002).

Metabolically, when radio-labeled pentosidine was administered intravenously to rats, $20 \%$ was recovered intact in the urine, the remainder being metabolized or changed by unknown processes (Miyata et al. 1998). AGEs would not be expected to be typical substrates for enzyme systems involved in detoxification by phase 1 and 2 enzymes. The highly watersoluble AGEs in particular may not be substrates for the phase 1 enzymes in the fatty membranes of the endoplasmic reticulum. Most AGEs also lack typical side groups for phase 2 coupling reactions, except acidic groups for esterification.

As LMW AGEs are rapidly absorbed, they should also be readily cleared by glomerular filtration and excreted with relatively short half-lives. The renal clearance of free CML and CEL after an intravenous injection in rats was rapid with over $87 \%$ detected in the urine after $2 \mathrm{~h}$ (Bergmann et al. 2001). It has been reported from studies in rats that only $29 \%$ of CML could be recovered in urine and $22 \%$ in feces after a 10-day diet containing high levels of HMW CML (Somoza et al. 2006). The renal excretion of AGEs (measured with a nonspecific ELISA method) has been estimated to be about $30 \%$ of the absorbed amount in healthy subjects, decreasing to levels as low as $5 \%$ in renal disease patients (Koschinsky et al. 1997). When well-defined amounts of LMW pyrraline 
and pentosidine in selected food items were specifically investigated in humans large amounts of free pyrraline and pentosidine were recovered in the urine, $50 \%$ and $60 \%$, respectively. In contrast, when food with HMW pentosidine was consumed only $2 \%$ was recovered in urine (Foerster et al. 2005). Urinary excretion rates in healthy adolescents after intake of a low or a high CML diet have been reported to be $24 \%$ and $15 \%$ of dietary intake respectively (DelgadoAndrade et al. 2012).

Any deterioration in renal function results in AGE accumulation which can lead to endothelial perturbation and hence vascular disease (Bierhaus A et al. 1998b). In vitro studies have proposed that insulin also contributes to AGE elimination from the plasma via the IRS and phosphatidyl-inositol-3-OH kinase (PI3 kinase) pathway (Sano et al. 1998). This pathway is thought to be vasculo-protective, leading to a rise in nitric oxide as well as facilitating insulin-mediated glucose transport in adipocytes and skeletal muscle. Recent human studies revealed that about $10 \%$ of diet-derived AGEs were absorbed, twothirds of which remained in the body and only one-third of the absorbed AGEs was excreted into the urine within 3 days from ingestion (Koschinsky et al. 1997; He et al. 1999).

\section{Mechanism of action}

AGEs are known to induce effects within the body by two separate mechanisms: structural deformation or cross-linking of body proteins, and interaction with AGE receptors. The structural deformation or cross-linking of body proteins has mainly been related to the increased endogenous production of AGEs in diabetes and to the co morbidities of diabetes (Baynes and Thorpe 1999). AGE cross-linking with proteins depends on both the sugar concentration and the turnover rate of body proteins. Long-lived proteins are therefore more often modified by AGEs (Brownlee 1995). The proteins collagen and low-density lipoprotein (LDL) are also sensitive to AGE cross-linking, resulting in increased arterial stiffness and decreased uptake by LDL receptors (Zieman and Kass 2004). AGE cross-linking to lens proteins induces functional changes, for example in lens crystallins (Bucala and Cerami 1992), while AGE cross-linking in renal tissues increases the thickening of the basement membrane (Ahmed 2005a). In general the accumulation of AGEs in the different organs seem to be involved in diabetic complications, including those of the retina, kidneys, nerves, and atherosclerotic plaques (Poulsen et al. 2013).

One of the main mechanisms of action of AGEs may be via AGE - sensitive receptors. These include a receptor for AGEs (RAGE), oligosaccharyl transferase complex protein 48 (OST-48 or AGER1), 80 K-H protein (AGER2), galectin-3 (AGER3), and scavenger receptors. The AGE receptors are expressed in a wide range of cells, e.g., monocytes, macrophages, endothelial cells, adipocytes, and podocytes. AGEs can also bind to lysozyme and lactoferrin (Thornalley 1998). Among the AGE binding proteins, RAGE and AGER 1 seem to be the most important, and in particular RAGE has been thoroughly investigated (Han et al. 2011).

\section{Age receptors-RAGE and their post AGE receptor effects}

Several different receptors for AGEs have been identified and include macrophage scavenger receptor Types I and II, receptor for AGE (RAGE), oligosaccaharyl transferase-48 (AGER1), $80 \mathrm{~K}-\mathrm{H}$ phosphoprotein (AGE-R2) and galectin-3 (AGER3) (Stitt et al. 1997a). They are expressed on a wide range of cells including smooth muscle cells, monocytes, macrophages, endothelial cells, podocytes, astrocytes and microglia (Thornalley 1998).

The best characteried AGE receptor is RAGE, which is a multigland member of the immunoglobulin superfamily (Schmidt et al. 1996) and initiates the intracellular signalling that disrupts cellular function through its recognition and binding of AGEs. The RAGE receptor is thought to act as a scavenger and mediate intracellular signalling. In vitro studies have shown that AGE-RAGE binding on macrophages and microglia leads to oxidant stress and activation of the transcription factor NF- B (Fig. 3) (Lander et al. 1997; Yan 1994; Schmidt et al. 1994). The NF- B is a free radical sensitive transcription factor that modulates gene transcription for endothelin-1, tissue factor and thrombomodulin (Bierhaus et al. 1998a). It has also been linked to states of anti-oxidant depletion induced by AGE, with a reduction in glutathione, vitamin C and nitric oxide (Bierhaus et al. 1997). A "two hit" model has been proposed to explain vascular dysfunction involving AGE (Schmidt et al. 1999). It involves an initial AGE-RAGE interaction resulting in cellular activation and inflammation, followed by lipoprotein accumulation in atherosclerosis, leading to chronic inflammation and further accelerated atherosclerosis. Hypertension is generally asymptomatic, it is related to a higher risk for development of heart failure, particularly diastolic heart failure. Several mechanisms underlying diastolic heart failure have been proposed. Diastolic heart failure is generally associated with increased myocardial stiffness, which may be caused by modifications of collagen in the extracellular matrix. One important modification of collagen is increased cross-linking by the formation of advanced glycation end products (AGEs). These are carbohydrate and lipid dependent modifications of protein, formed by oxidative and non-oxidative reactions. The accumulation of AGEs (via glycation, glycoxidation, lipoxidation or generation of carbonyl compounds) is known as carbonyl stress, a phenomenon that has been observed in both diabetes and uraemia 
Fig. 3 AGE-RAGE interaction and NF- B activation

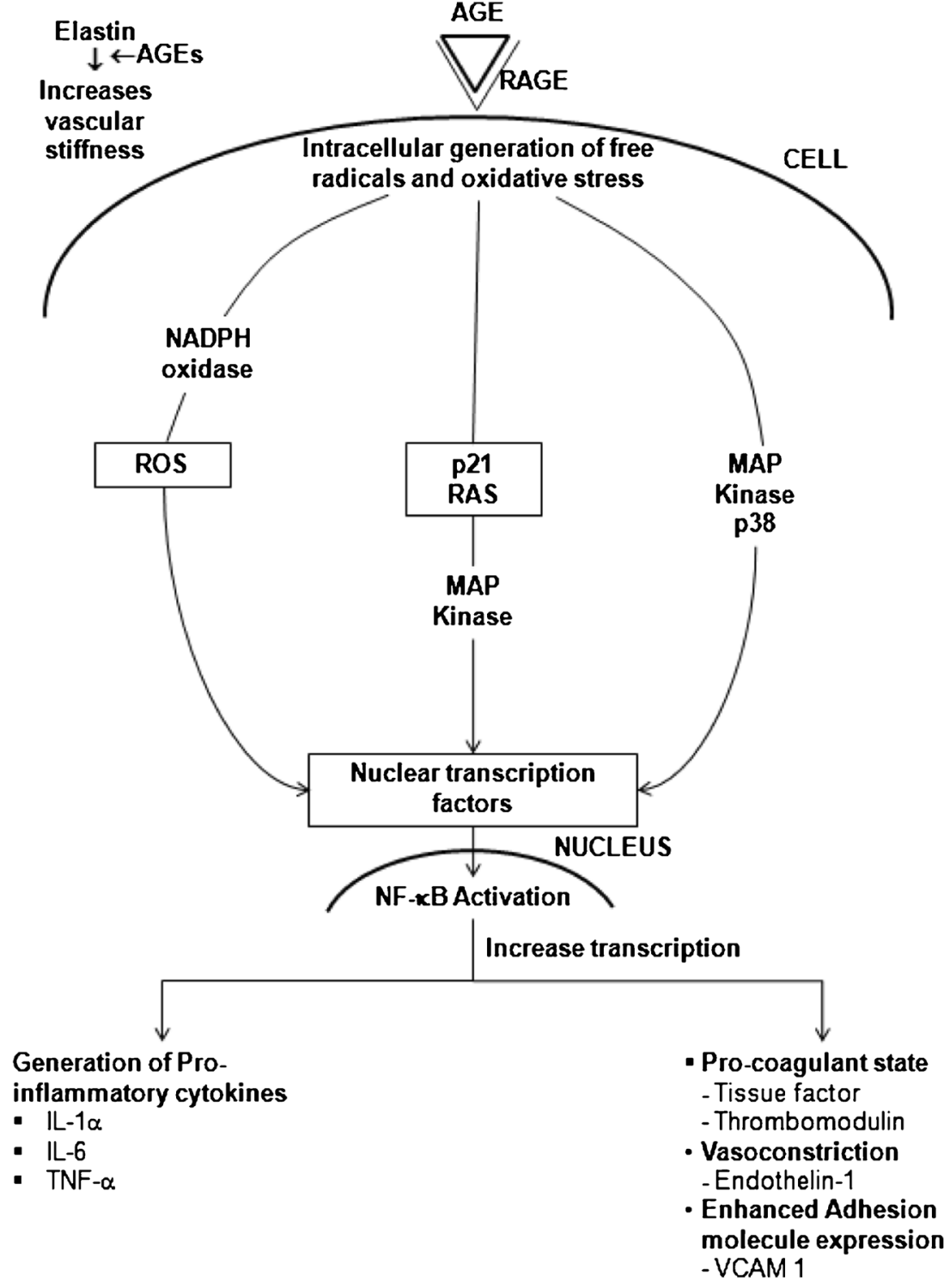

and has also been proven to play a role in the accelerated atherosclerosis and vascular dysfunction even independently of these conditions (Hartog et al. 2007).

Extracellularly, the mechanisms through which AGEs contribute to diabetic complications include the following: (1) formation of cross-links between key molecules in the basement membrane of the extracellular matrix (ECM) thereby permanently altering cellular structure and (2) interaction of AGEs with RAGE on cell surfaces, altering cellular function. AGEs can alter properties of the large matrix proteins collagen, vitronectin, and laminin, through AGE-AGE intermolecular covalent bonds, or crosslinking (Howard et al. 1996; Schmidt et al. 1995). AGE cross-linking on type I collagen and elastin causes an increase in the area of ECM, resulting in increased stiffness of the vasculature (Haitoglou et al. 1992; Corman et al. 1998).
Other receptors, like AGE-R1 (oligosaccharyl transferase48), AGE-R2 (80 K-H phosphoprotein) and AGE-R3 (galectin-3) are also able to recognie and bind AGE ligands, but they have not been shown to transducer cellular signals after engagement by AGEs (Stitt et al. 1997b).

Studies suggest that it is the rate of accumulation rather than the absolute concentration of AGE that is important. In vitro and diabetic animal model evidences that AGE accumulation has a number of important consequences at the tissue level. These include lipid peroxidation and endothelial dysfunction and inappropriate cellular activity with cytokine release (Makita et al. 1996; Vlassara and Bucala 1996). Alterations in cell spreading and other structural changes such as crosslink formation have also been described (Makita et al. 1996; Vlassara and Bucala 1996; Sano et al. 1998). 


\section{Approaches for quantification of AGEs}

The broad range of polarities and the physical properties of AGEs make purification of samples prior to analysis and the retention and separation of AGEs by chromatography challenging. The ultimate goal is to quantify as many as possible, and ideally all AGEs in one run. However, most of the analytical work so far has been done on CML, and there is no commonly accepted method for detecting AGEs, or any commercially available kits. Standardized methods and reference materials are needed if different laboratories are to compare AGE results in a meaningful way (Smit and Lutgers 2004).

The methods for quantification of AGEs can be divided into instrumental and immunochemical methods. The instrumental methods include high performance liquid chromatography (HPLC) methods coupled to various detectors, including diode array detector (DAD) (Rufian-Henares et al. 2004), fluorescence detector (Hartkopf et al. 1994), tandem mass spectrometer (MS/MS) (Ahmed et al. 2002) and gas chromatography (GC) coupled with MS (Charissou et al. 2007). The immunochemical method is primarily enzyme-linked immunosorbent assay (ELISA) (Goldberg et al. 2004).

HPLC-DAD has been used to detect the pyrraline content in certain foods, e.g., enteral formula ( Rufian-Henares et al. 2004), but to use this method, UV active compounds are needed. Fluorescence has been used as a detector for AGEs that are either fluorescent, such as pentosidine, or non-fluorescent, such as CML, after derivatization with o-phthaldialdehyde (Hartkopf et al. 1994). Methods have also been developed recently to measure the concentration of AGEs directly in the skin noninvasively by fluorescent techniques (Meerwaldt et al. 2005). GC-MS has been used to determine the amount of CML in different food samples, including milk and meat. When GC-MS is used, volatile derivatives are needed, introducing an extra step prior to analysis (Charissou et al. 2007). LC-MS/MS has been used for different AGEs, but mostly CML (Zhang et al. 2009). The use of LC-MS/MS increases the sensitivity compared to UV and fluorescence and needs no derivatization. The ELISA technique has been used extensively to measure AGEs, including nonspecific AGEs (Koschinsky et al. 1997; Makita et al. 1992), CML (Goldberg et al. 2004; Uribarri et al. 2010), and MG - derivatives (Uribarri et al. 2010). A competitive ELISA with an apparently more specific anti-CML monoclonal antibody (4G9) has also been developed and used to measure CML expressed as AGE units per $100 \mathrm{~g}$ food (Goldberg et al. 2004; Uribarri et al. 2010).

However, it has been shown that the sole use of ELISA does not give satisfying results (Henle 2008). It was suggested that a matrix effect could have led to these conflicting results (Assar et al. 2009).

\section{Dietary advanced glycation end-products (d-AGEs) and their health implications}

Nutrient composition, temperature and method of cooking can affect the formation of AGEs in foods. $F$ ats or meat-derived products processed by high heat such as broiling and oven frying contain more AGEs than carbohydrates boiled for longer periods (Uribarri et al. 2005; Goldberg et al. 2004). That is, in the absence of lipids and proteins or heat, sugar content does not necessarily correlate with AGE values in the food. And, the absence of sugars does not necessarily predict low AGE content, as in preparations containing preformed AGElike caramel additives (Koschinsky et al. 1997).

Food-derived AGEs induce protein cross-linking and intracellular oxidant stress similar to their endogenous counterparts when tested in vitro using human-derived endothelial cells (Cai et al. 2002). These prooxidant and pro inflammatory properties are also found in the circulating AGE fractions derived from these exogenous AGEs. Experiments performed in different animal models have established a significant role for dietary AGEs in inducing type 1 diabetes mellitus in nonobese diabetic (NOD) (Peppa et al. 2003b). In a group of diabetic subjects, dietary AGE restriction was associated with significant reduction of two markers of inflammation, plasma $\mathrm{C}$-reactive protein (CRP) and peripheral mononuclear cell TNF- $\alpha$, as well as of VCAM-1, a marker of endothelial dysfunction (Vlassara et al. 2002). These observations were later extended to chronic renal failure patients on maintenance peritoneal dialysis, in whom dietary AGE restriction was associated with a parallel reduction of serum AGEs and CRP (Uribarri et al. 2003). The parallel changes of serum AGEs and CRP following dietary AGE modifications are highly suggestive of a role for dietary AGEs in inducing inflammation.

\section{Role of food-derived AGEs in vascular complications in diabetic animals}

With regards to complications of diabetes, several different animal models have been used to examine the role of dietary AGEs in the development of kidney disease. In diabetic mouse models, there has been reports of both protective (Zheng et al. 2002) and disparate effects (Tan et al. 2010) of diets low in AGEs in development of diabetic nephropathy. In remnant kidney models in rats, proteinuria increased during feeding with high AGE diets (Feng et al. 2007; Sebekova et al. 2003). Furthermore, high AGE diets were shown to accelerate progression of renal fibrosis (Feng et al. 2007). In addition, in a mouse model of obesity, renal impairment developed when high AGEs and a high fat diet were combined (Harcourt et al. 2011). An AGE-poor diet that contained four- to five-fold lower AGE contents for 2 months also decreased serum levels of AGEs and markedly reduced tissue AGEs and RAGE 
expression, numbers of inflammatory cells, tissue factor, VCAM-1, and MCP-1 levels in diabetic apolipoprotein Edeficient mice (Lin et al. 2003).

\section{Role of food-derived AGEs in ageing}

Aging is associated with increased oxidative stress generation and AGE formation (Cai et al. 2007). A life-long restriction of AGE containing diet reduces oxidative stress generation and AGE accumulation which are associated with RAGE and p66 suppression, resulting in extension of lifespan in mice (Cai et al. 2007). Oral intake of AGE-containing foods also determines the effects of calorie restriction on oxidant stress, agerelated diseases, and lifespan (Cai et al. 2008). These observations suggest that restriction of AGE-rich diet may be a novel therapeutic target for prevention of age associated various disorders.

In food analyses, CML has been the most widely used marker for AGEs (Ames 2008; Assar et al. 2009). The CML content of the same food item can be increased up to 200-fold by increasing the temperature and conditions used in cooking. The CML concentrations of various foods vary widely from about $0.35-0.37 \mathrm{mg} \mathrm{CML} / \mathrm{kg}$ food for pasteurized skimmed milk and butter to about $11 \mathrm{mg} \mathrm{CML} / \mathrm{kg}$ food for fried minced beef and $37 \mathrm{mg} \mathrm{CML} / \mathrm{kg}$ food for white bread crust. Fried meat, sausage, and cookies are high in CML. (Assar et al. 2009; Hartkopf et al. 1994). Other foods that are high in AGEs include many commercial breakfast cereals (DelgadoAndrade et al. 2006), roasted nuts and seeds (Yaacoub et al. 2008), ice cream (Drusch et al. 1999), and barbecue sauces (Chao et al. 2009). High concentrations of methylglyoxal, an intermediate product of the Maillard reaction, are found in commercial soft drinks that contain high fructose corn syrup (Tan et al. 2010). Methylglyoxal is reactive and readily modifies lysine or arginine residues of proteins to form carboxyethyllysine and hydroimidazolones (Assar et al. 2009). Pasteurized milk and sterilized milk contain much higher CML concentrations than raw milk (Ahmed et al. 2005b). Evaporated whole milk contains high concentrations of CML, probably due to the high temperatures used in processing the milk (Assar et al. 2009). Infant formula contains high concentrations of AGEs (Birlouez-Aragon et al. 2004). Commercial infant formulas contain a 70fold higher level of CML than human breast milk, and infants fed infant formula had significantly high plasma CML than breast-fed infants (Sebekova et al. 2008). Foods that are either eaten raw or cooked at lower temperatures are relatively low in AGEs, and such foods include raw fruits and vegetables, raw fish, raw nuts, yoghurt, tofu, pasta, boiled rice, boiled potatoes, and other boiled or simmered foods.

Other processes, besides the formation of AGEs, also take place in food during cooking. It is well-known and described in the literature that heating of food induces degradation and oxidation of heat-sensitive compounds, including vitamins and other bioactive compounds (Dhuique-Mayer et al. 2007; Klopotek et al. 2005; Vikram et al. 2005). A high versus low AGE diet made by differences in heat treatment will, therefore, have dissimilar content of such compounds and this has also been confirmed when it has been measured in intervention studies ( Birlouez-Aragon et al. 2010). This is a problem, because effects of high AGE diets cannot be directly related only to the AGE content. It cannot be ruled out that a lower content of a range of heat-sensitive nutrients in the diet, e.g., vitamin C, E, and thiamine, could also contribute to these negative effects. Accordingly, AGE levels in body fluids might be markers of the inflammatory and oxidative burden. For example, marginal thiamine deficiency has been shown to increase both markers of oxidative stress and of reactive dicarbonyls (Depeint et al. 2007; Shangari et al. 2005) and vitamin B6 can also affect AGE formation. Furthermore, extensive heat processing of food can generate Maillard-derived antinutritional and toxic compounds (Friedman 1992; PerezLocas and Yaylayan 2010). Such compounds include acrylamide (Gokmen and Senyuva 2012; Tareke et al. 2002), heterocyclic aromatic amines (Skog et al. 1998) and 5-hydroxymethylfurfural (Janzowski et al. 2000), all of which are suspected carcinogens. Thus, simply referring the effects of a less heat-treated diet to effects of AGEs is problematic; the consequences of cooking for the concentrations of AGEs as well as other heat-derived compounds are not tested in the majority of the dietary AGE studies. Only one study has reported the content of acrylamide and 5-hydroxymethylfurfural and they were found to be significantly higher in the high AGE diet (Pouillart et al. 2008).

Nevertheless, this shows there is a large range of potentially harmful compounds generated by heat and points to the essential problem with identifying the active compounds. Harmful effects of high AGE diets cannot be directly related to the AGE content. Studies with well-defined compounds outside a complex food matrix (e.g., synthetically produced AGEs) are needed to identify individual effects. Moreover, AGEs are often investigated and discussed as a whole, even though they are a large and heterogeneous group of compounds. The heterogeneity of AGEs makes it difficult to conclude which of these compounds are biologically active and exert which specific effects in vivo. Within the large range of MRPs, not only AGEs have been identified, but also compounds with potential beneficial effects have been described. Melanoidins have been associated with health benefits in some studies and antioxidative properties of MRPs have been observed in a human intervention study (Poulsen et al. 2013). 


\section{Anti-AGE therapies}

As modern diets are largely heat-processed and as a result contain high levels of advanced glycation end products (AGEs), it becomes necessary to control the AGEs content in the food. The formation of AGEs is a part of normal metabolism, but if excessively high levels of AGEs are reached in tissues and the circulation they can become pathogenic (Ulrich and Cerami 2001). The pathologic effects of AGEs are related to their ability to promote oxidative stress and inflammation by binding with cell surface receptors or cross-linking with body proteins, altering their structure and function (Eble et al. 1983; Vlassara 2001; Schmidt 1999).

The varying conditions of water and heat play a significant role in the production of dAGE content. As scrambled eggs prepared in an open pan over medium-low heat had about one half the dAGEs of eggs prepared in the same way but over high heat. Similarly, poached or steamed chicken had less than one fourth the dAGEs of roasted or broiled chicken. Thus, frying, broiling, grilling and roasting yielded more dAGEs compared to boiling, poaching, stewing, and steaming. Moreover, microwaving also did not raise dAGE content to the same extent as other dry heat cooking methods for the relatively short cooking times (6 min or less) that were tested. In nut shell, higher temperature and lower moisture levels coincided with higher dAGE levels (Uribarri et al. 2010).

Endogenous inhibitors of AGE formation may be pharmaceuticals, food-derived compounds, endogenous scavengers or enzymes. Endogenously, AGE formation is limited by detoxifications pathways. This relates particularly to detoxification of potent AGE precursors. Of importance is the glyoxalase system, which is an enzymatic defence against MG (methyl glyoxal) glycation catalyzed by reduced glutathione. More than $99 \%$ of endogenously formed MG is converted to harmless products (mainly lactate) by the glyoxalase system (Rabbani and Thornalley 2012). Polymorphisms are known to affect enzyme activity (Peculis et al. 2013), and have been strongly implicated in diabetic complications and atherosclerosis (Wu et al. 2011). Interestingly, the glyoxalase system is under control of the transcription factor, Nrf-2, which is also controlling phase 2 defence enzymes and apoptosis (Xue et al. 2012). This provides a potential way to up-regulate glyoxalase and reduce dicarbonyl formation by exogenous factors, including several plant secondary metabolites found in the diet.

Exogeneously, both synthetic compounds as well as natural products have been evaluated as AGE inhibitors. Although some synthetic compounds demonstrated strong inhibitory activities against the formation of AGEs or in breaking protein cross links caused by Maillard reaction in vivo, they may also lead to severe side effects. In this regard, some plant extracts have been evaluated for their effects on the formation of AGEs in recent years (Gugliucci and Menini 2002; Lee et al. 2006; Yamaguchi et al. 2000). It is noted that the inhibitory effects of most of these plant extracts on the formation of AGEs are mainly contributed by the large amount of phenolic antioxidants they contain. As free radicals are involved in the formation of AGEs, it is reasonable to expect that phenolic antioxidants can inhibit the formation of AGEs.

Among the synthetic AGE inhibitors, aminoguanidine, the first AGE inhibitor is considered an effective AGE inhibitor in both in vitro and in vivo conditions. Aminoguanidine has a guanidine group similar to arginine and primarily acts as a scavenger of $\alpha$-dicarbonyls i.e., at the pre-Amadori stage in the Maillard reaction. The reduction of AGE formation by aminoguanidine attenuates the effects of diabetes on large arteries. Aminoguanidine treatment increases arterial elasticity as measured by aortic input impedence, static compliance, and left ventricular afterload in diabetic rats (Corman et al. 1998). In addition, aminoguanidine decreases vascular AGE accumulation and the severity of atherosclerosis plaque in diabetic rats (Forbes et al. 2004).

Beans are recommended as suitable foods for diabetic patients in the past mainly for their high fibre and protein contents. Four kinds of beans including mung bean (Vigna radiata) black bean (Phaseolus vulgaris L.), soybean (Glycine max) and cowpea (Vigna unguiculata) were investigated for trapping of methylglyoal, a key intermediate compound for the formation of AGEs. The aqueous alcohol extracts of all beans examined have showed significant inhibitory activities at a concentration of $500 \mathrm{ppm}$ with $80.4 \%$ inhibition for mung bean, $72.1 \%$ for black bean, $70.1 \%$ for soybean, and $67.3 \%$ for cowpea extract, respectively (Peng et al. 2008a). Various phenolic antioxidants from plant extracts have been found to inhibit the formation of AGEs, and their inhibition of free radical generation in the glycation process and subsequent inhibition of modification of proteins have been considered as the major mechanisms for mediating their anti-glycation activities. Total phenolics were determined and it was found that mung bean extract had the highest phenolic content and anti-glycation activities of these beans were highly correlated with their total phenolic contents $\left(R^{2}=0.95\right)$. Two major phenolic compounds from mung bean, vitexin and isovitexin were studied for their activities in direct reapping of methylglyoxal, a key intermediate compound for the formation of AGEs (Peng et al. 2008b).

Low or acidic $\mathrm{pH}$ also arrests the new AGE development. For example, beef that was marinated for $1 \mathrm{~h}$ in lemon juice or vinegar formed less than half the amount of AGEs during cooking than the untreated samples (Uribarri et al. 2010). Green tea is known well for diabetic people in several ways. It reduces blood glucose level; improves sensitivity to insulin and enhances antioxidant defenses (Babu et al. 2006; Wu et al. 2004). Furthermore, green tea inhibits the formation of AGEs in an in vitro bovine serum albumin (BSA)/glucose system and in the collagen of aged rats and diabetic rats (Babu et al. 2008; Nakagawa et al. 2002; Rutter et al. 2003). 
Table 2 Possible agents and their method of action for Anti-AGE treatments

\begin{tabular}{|c|c|c|}
\hline Drug/Agent & Source & Method of action \\
\hline Vitexin and Isovitexin & Soybean & Free radical scavenging/metal ion trapping \\
\hline Aminoguanidine & Synthetic & $\begin{array}{l}\text { - Reacts with derivatives of early glycation products that are not bound on proteins (3- } \\
\text { deoxyglucosone) } \\
\text {-Inhibits lipid peroxidation and oxygen induced apoptosis } \\
\text { Prevents cross-link formation }\end{array}$ \\
\hline Vitamin C \& E & Fruits & -Vitamin E blocks the protein glycation by inhibiting MDA (malondialdehyde) formation \\
\hline Thymoquinone & Nigella sativa & $\begin{array}{l}\text {-Inhibited the early stage of glycation } \\
\text { Strongly inhibited the post Amadori glycation }\end{array}$ \\
\hline Epigallocatechin gallate & Green tea & Trap MGO (methylglyoxal) under physiological conditions \\
\hline Rutin & Tomato & $\begin{array}{l}\text {-Inhibits auto-oxidation of glucose } \\
\text { - Free radical scavenging/metal ion trapping } \\
\text { Trapping of reactive dicarbonyl and reactive oxygen species }\end{array}$ \\
\hline Microalgal extract & $\begin{array}{l}\text { Chlorella and diatom } \\
\text { Nitzchiva laevis }\end{array}$ & Carotenoids and polyunsaturated fatty acids are supposed to have antiglycative properties. \\
\hline $\begin{array}{l}\text { Aspirin (Acetyl- } \\
\text { salicylic acid) }\end{array}$ & Synthetic & $\begin{array}{l}\text { Inhibit glycation by acetylating free amino groups of a protein, thereby blocking the } \\
\text { attachment of reducing sugars }\end{array}$ \\
\hline Vitamin B1 and B6 & Whole grain cereals & $\begin{array}{l}\text {-Prevents the degradation of protein-Amadori intermediates to protein-AGE products } \\
\text {-Reduces hyperlipidemia and prevents AGE formation } \\
\text { Scavenge reactive carbonyl compounds }\end{array}$ \\
\hline Penicillamine & $\begin{array}{l}\text { Amino acid metabolite of } \\
\text { penicillin }\end{array}$ & -Reduce the level of AGEs through decreasing the formation of Amadori products \\
\hline
\end{tabular}

Different AGE inhibitors suppress AGE formation at different stages of glycation (Table. 2). For example, aspirin (acetylsalicylic acid) is known to inhibit glycation by acetylating free amino groups of a protein, thereby blocking the attachment of reducing sugars (Caballero et al. 2000; Malik and Meek 1994) at the early stage of the glycation process. The inhibitory activities against AGE formation of various vitamin B1 and B6 derivatives such as pyridoxamine (Khalifah et al. 1999; Metz et al. 2003; Voziyan et al. 2002) and thiamine pyrophosphate (Booth et al. 1997) have mainly been attributed to their abilities to scavenge reactive carbonyl compounds (Ahmed et al. 2005a; Voziyan et al. 2002). In addition, penicillamine could reduce the level of AGEs through decreasing the formation of Amadori products (Jakus et al. 1999; Keita et al. 1992).

Numerous traditional herbal infusions, including Luobuma (Apocynum venetum L.), Nagarmotha (Cyperus rotundus), Mate (Ilex paraguariensis) and Guava (Psidium guajava L.) exhibit potent anti-glycation capacities (Ardestani and Yazdanparast 2007; Gugliucci et al. 2009; Hsieh et al. 2005; Yokozawa and Nakagawa 2004). All herbal infusions inhibited the glucose-mediated formation of fluorescent AGEs in a dose-dependent manner at dilutions of 10-fold to 40-fold. At a ten-fold dilution, balm, mint, black tea, green tea and sage almost completely inhibited the formation of fluorescent AGEs. At a 20-fold dilution, only balm retained its capacity to inhibit totally the formation of fluorescent AGEs. Accordingly, comparing the antiglycation capacities of different herbal infusions based on the experimental results obtained from a 40-fold dilution seems logical. At a 40-fold dilution, the anti-glycation capacity of herbal infusions followed the order, balm $(89.8 \%)>\operatorname{mint}(47.8 \%)>$ black tea $(38.0 \%)>$ green tea $(35.4 \%)$, sage $(33.4 \%)$ and common verbena $(30.4 \%)>$ rosemary $(18.8 \%)>$ lemongrass $(3.0 \%)$ (Ho et al. 2010).

As a well-known nutraceutical product, grape seed extract (GSE) is an abundant source of catechins and proanthocyanidins with a strong antioxidant and free radical scavenging activity (Liang et al. 2004). Peng et al. (2010) studied the effects of GSE on the formation of $N^{\varepsilon}-$ (carboxy-methyl) lysine (CML) in bread. Besides introducing antioxidant activity to bread, GSE also appeared to attenuate CML content in bread crust. In particular, adding 600 and $1000 \mathrm{mg}$ of GSE to bread $(500 \mathrm{~g})$ led to over $30 \%$ and $50 \%$ reduction in bread crust CML content, respectively. Strong antioxidant activities of catechins and proanthocyanidins abundant in GSE may contribute to the reduction of CML in GSE-fortified bread (Peng et al. 2010). On the other hand, catechins and proanthocyanidins proved to be able to scavenge the intermediate dicarbonyls (such as methylglyoxal, glyoxal) (Lo et al. 2006; Peng et al. 2008a) in the glycation process, which may also decrease the CML content of GSE-fortified bread.

Based on the current evidence, individuals with diabetes and/ or kidney disease seem to be the population groups deriving most benefit from an AGE-restricted diet and potentially from inhibition of AGE-formation and its associated actions in the body. 


\section{How to win the battle against AGEs/ fight against AGEs in kitchen}

On an average, the intake of dAGE in a cohort of healthy adults from the New York city areas was found to be 14,700 $\pm 680 \mathrm{AGE} \mathrm{kU} /$ day (Uribarri et al. 2007). By smart food selection and by changing the way of cooking, the level of AGEs could be lowered in the diet. Overall, moving away from foods high in fat, red meat and processed and fast foods and toward a diet focused more on fruits and vegetables, whole grains and lean meats and fish will not only reduce the AGE intake but help to meet other important nutritional goals as well.

Reducing dAGE may be especially important for people with diabetes, who generate more endogenous AGEs than those without diabetes and for those with renal disease, who have impaired AGE clearance from the body (Koschinsky et al. 1997). Recently there has been heightened interest in therapeutic diets that are higher in protein and fat and lower in carbohydrate for weight loss, diabetes and cardiovascular diseases. This type of dietary pattern may substantially raise dAGE intake and thus contribute to health problems over the long term. A safe and optimal dAGE intake for the purposes of disease prevention has yet to be established.

Some tips to win the battle against AGEs in kitchen are as:

- Use of lower cooking temperatures over high cooking temperatures.

- Steming, stewing and poaching are be the cooking methods than frying, grilling and roasting.

- Be wary of browning.

- Higher temperature and lower moisture levels in food during cooking increase dAGE levels.

- Phenolic antioxidants (e.g., in beans) can inhibit the formation of AGEs.

- Addition of acids (e.g., vinegar, lemon juice) lowers AGE levels.

- Green tea inhibits formation of AGEs.

- Cook fresh foods as possible.

- Eat more often at home.

Finally, as Jaime Uribarri says the research on AGEs doesn't mean you have to swear off grilled steak or fried chicken forever. As with most dietary issues, the key is moderation: "Just diminish your exposure".

\section{References}

Ahmed N, Argirov OK, Minhas HS, Cordeiro CAA, Thornalley PJ (2002) Assay of advanced glycation endproducts (AGEs): surveying AGEs by chromatographic assay with derivatization by 6 -
aminoquinolyl-N-hydroxysuccinimidyl-carbamate and application to N-epsilon-carboxymethyl-lysine- and N-epsilon-(1-carboxyethyl) lysine-modified albumin. Biochem J 364:1-14

Ahmed N, Luthen R, Haussinger D, Sebekova K, Schinzel R, Voelker W et al (2005a) Increased protein glycation in cirrhosis and therapeutic strategies to prevent it. Ann N Y Acad Sci 1043:718-724

Ahmed N, Mirshekar-Syahkal B, Kennish L, Karachalias N, BabaeiJadidi R, Thornalley PJ (2005b) Assay of advanced glycation endproducts in selected beverages and food by liquid chromatography with tandem mass spectrometric detection. Mol Nutr Food Res 49:691-699

Ames JM (2008) Determination of Ne-(carboxymethyl) lysine in foods and related systems. Ann N Y Acad Sci 1126:20-24

Ardestani A, Yazdanparast R (2007) Cyperus rotundus suppresses AGE formation and protein oxidation in a model of fructose-mediated protein glycoxidation. Int J Biol Macromol 41:572-578

Assar SH, Moloney C, Lima M, Magee R, Ames JM (2009) Determination of $\mathrm{Ne}$-(carboxymethyl)lysine in food systems by ultra performance liquid chromatography-mass spectrometry. Amino Acids 36:317-326

Babu PVA, Sabitha KE, Shyamaladevi CS (2006) Therapeutic effect of green tea extract on oxidative stress in aorta and heart of streptozotocin diabetic rats. Chem Biol Interact 162(2):114-120

Babu PVA, Sabitha KE, Shyamaladevi CS (2008) Effect of green tea extract on advanced glycation and cross-linking of tail tendon collagen in streptozotocin induced diabetic rats. Food Chem Toxicol 46:280-285

Baynes JW, Thorpe SR (1999) Role of oxidative stress in diabetic complications: a new perspective on an old paradigm. Diabetes 48:1-9

Bergmann R, Helling R, Heichert C, Scheunemann M, Mading P, Wittrisch H, Johannsen B, Henle T (2001) Radio fluorination and positron emission tomography (PET) as a new approach to study the in vivo distribution and elimination of the advanced glycation endproducts $\mathrm{N}$ epsilon-carboxymethyllysine (CML) and $\mathrm{N}$ epsilon-carboxyethyllysine (CEL). Nahrung 45:182-188

Bierhaus A, Chevion S, Chevion M et al (1997) Advanced glycation endproducts induced activation of NF- $x \mathrm{~B}$ is suppressed by $\alpha$-lipoic acid in cultured endothelial cells. Diabetes 46:1481-1490

Bierhaus A, Hofmann MA, Ziegler R, Nawroth PP (1998a) AGE and their interaction with AGE-receptors in vascular disease and diabetes. I. The AGE concept. Cardiovasc Res 37:586-600

Bierhaus A, Ziegler R, Nawroth PP (1998b) Molecular mechanisms of diabetic angiopathy clues for innovative therapeutic interventions. Horm Res 50(Suppl 1):1-5

Birlouez-Aragon I, Pischetsrieder M, Leclère J et al (2004) Assessment of protein glycation markers in infant formulas. Food Chem 87:253259

Birlouez-Aragon I, Saavedra G, Tessier FJ, Galinier A, Ait-Ameur L, Lacoste F, Niamba CN, Alt N, Somoza V, Lecerf JM (2010) A diet based on high-heat-treated foods promotes risk factors for diabetes mellitus and cardiovascular diseases. Am J Clin Nutr 91:1220-1226

Booth AA, Khalifah RG, Todd P, Hudson BG (1997) In vitro kinetic studies of formation of antigenic advanced glycation end products (AGEs) Novel inhibition of post-Amadori glycation pathways. J Biol Chem 272:5430-5437

Brownlee M (1995) Advanced protein glycosylation in diabetes and aging. Annu Rev Med 46:223-234

Brownlee M, Vlassara H, Cerami A (1984) Nonenzymaic glycosylation and the pathogenesis of diabetic complications. Annu Int Med 101: $527-537$

Bucala R, Cerami A (1992) Advanced glycosylation: chemistry, biology, and implications for diabetes and aging. Adv Pharmacol 23:1-34

Caballero F, Gerez E, Batlle A, Vazquez E (2000) Preventive aspirin treatment of streptozotocin induced diabetes: blockage of oxidative status and revertion of heme enzymes inhibition. Chem Biol Interact $126: 215-225$ 
Cai W, Cao QD, Zhu L et al (2002) Oxidative stress-inducing carbonyl compounds from common foods: novel mediators of cellular dysfunction. Mol Med 8:337-346

Cai W, He JC, Zhu L, Chen X, Wallenstein S, Striker GE, Vlassara H (2007) Reduced oxidant stress and extended lifespan in mice exposed to a low glycotoxin diet: association with increased AGER1 expression. Am J Pathol 170:1893-1902

Cai W, He JC, Zhu L, Chen X, Striker GE, Vlassara H (2008) AGEreceptor- 1 counteracts cellular oxidant stress induced by AGEs via negative regulation of p66shc-dependent FKHRL1 phosphorylation. Am J Physiol Cell Physiol 294:145-152

Cerami C, Founds H, Nicholl I et al (1997) Tobacco smoke is a source of toxic reactive glycation products. Proc Natl Acad Sci U S A 94: 13915-13920

Chao PC, Hsu CC, Yin MC (2009) Analysis of glycative products in sauces and sauce-treated foods. Food Chem 113:262-266

Charissou A, Ait-Ameur L, Birlouez-Aragon I (2007) Evaluation of a gas chromatography/mass spectrometry method for the quantification of carboxymethyllysine in food samples. J Chromatogr A 1140:189194

Cordain L, Eaton SB, Sebastian A, Mann N, Lindeberg S, Watkins BA, O'Keefe JH, Brand-Miller J (2005) Origins and evolution of the western diet: health implications for the 21 st century. Am J Clin Nutr 81:341-354

Corman B, Duriez M, Poitevin P, Heudes D, Bruneval P, Tedgui A, Levy BI (1998) Aminoguanidine prevents age-related arterial stiffening andcardiac hypertrophy. Proc Natl Acad Sci U S A 95:1301-1306

Delgado-Andrade C, Rufián-Henares JA, Morales FJ (2006) Study on fluorescence of maillard reaction compounds in breakfast cereals. Mol Nutr Food Res 50:799-804

Delgado-Andrade C, Seiquer I, Garcia MM, Galdo G, Navarro MP (2011) Increased maillard reaction products intake reduces phosphorus digestibility in male adolescents. Nutr 27:86-91

Delgado-Andrade C, Tessier FJ, Niquet-Leridon C, Seiquer I, Pilar NM (2012) Study of the urinary and faecal excretion of nepsiloncarboxymethyllysine in young human volunteers. Amino Acids 43:595-602

Depeint F, Shangari N, Furrer R, Bruce WR, O’Brien PJ (2007) Marginal thiamine deficiency increases oxidative markers in the plasma and selected tissues in F344 rats. Nutr Res 27:698-704

Dhuique-Mayer C, Tbatou M, Carail M, Caris-Veyrat C, Dornier M, Amiot MJ (2007) Thermal degradation of antioxidant micronutrients in citrus juice: kinetics and newly formed compounds. J Agric Food Chem 55:4209-4216

Drusch S, Faist V, Erbersdobler HF ( 1999) Determination of Nepsiloncarboxymethyllysine in milk products by a modified reversed-phase HPLC method. Food Chem 65:547-553

Eble AS, Thorpe SR, Baynes JW (1983) Nonenzymatic glycosylation and glucose-dependent cross-linking of proteins. J Biol Chem 258: 9406-9412

Feng JX, Hou FF, Liang M, Wang GB, Zhang X, Li HY, Xie D, Tian JW, Liu ZQ (2007) Restricted intake of dietary advanced glycation end products retards renal progression in the remnant kidney model. Kidney Int 71:901-911

Finot PA, Magnenat E (1981) Metabolic transit of early and advanced maillard products. Prog Food Nutr Sci 5:193-207

Foerster A, Kuhne Y, Henle T (2005) Studies on absorption and elimination of dietary maillard reaction products. Ann N Y Acad Sci 1043: 474-481

Forbes JM, Yee LT, Thallas V, Lassila M, Candido R et al (2004) Advanced glycation end product interventions reduce diabetesaccelerated atherosclerosis. Diabetes 53:1813-1823

Friedman M (1992) Dietary impact of food processing. Annu Rev Nutr $12: 119-137$

Frye EB, Degenhardt TP, Thorpe SR, Baynes JW (1998) Role of the maillard reaction in aging of tissue proteins advanced glycation end product-dependent increase in imidazolium cross-links inhuman lens proteins. J Biol Chem 273:18714-18719

Garcia MM, Seiquer I, Delgado-Andrade C, Galdo G, Navarro MP (2009) Intake of Maillard reaction products reduces iron bioavailability in male adolescents. Mol Nutr Food Res 53:1551-1560

Gokmen V, Senyuva HZ (2012) Effects of some cations on the formation of acrylamide and furfurals in glucose-asparagine model system. Eur Food Res Technol 225:815-820

Goldberg T, Cai W, Peppa M, Dardaine V, Baliga BS, Uribarri J, Vlassara $\mathrm{H}$ (2004) Advanced glycoxidation end products in commonly consumed foods. J Am Diet Assoc 104:1287-1291

Gugliucci A, Menini T (2002) The botanical extracts of achyrocline satureoides and ilex paraguariensis prevent methylglyoxal-induced inhibition of plasminogen and antithrombin III. Life Sci 72:279-292

Gugliucci A, Markowicz Bastos DH, Schulze J, Ferreira Souza MF (2009) Caffeic and cholorogenic acids in ilex paraguariensis extracts are the main inhibitors of AGE generation by methylglyoxal in model proteins. Fitoterapia 80:339-344

Haitoglou CS, Tsilibary EC, Brownlee M, Charonis AS (1992) Altered cellular interactions between endothelial cells and nonenzymatically glucosylated laminin/type IV collagen. J Biol Chem 267:1240412407

Han SH, Kim YH, Mook-Jung I (2011) RAGE: the beneficial and deleterious effects by diverse mechanisms of actions. Mol Cells 31:9197

Harcourt BE, Sourris KC, Coughlan MT, Walker KZ, Dougherty SL, Andrikopoulos S, Morley AL, Thallas-Bonke V et al (2011) Targeted reduction of advanced glycation improves renal function in obesity. Kidney Int 80:190-198

Hartkopf J, Pahlke C, Lüdemann G, Erbersdobler HF (1994) Determination of Ne-carboxymethyllysine by a reserved-phase high-performance liquid chromatography method. J Chromatogr 672:242-246

Hartog JWL, Voors AA, Bakker SJL, Smit AJ, Veldhuisen DJ (2007) Advanced glycation end-products and heart failure: pathophysiology and clinical implications. Eur J Heart Fail 9:1146-55

He C, Sabol J, Mitsuhashi T, Vlassara H (1999) Dietary glycotoxins: inhibition of reactive products by aminoguanidine facilitates renal clearance and reduces tissue sequestration. Diabetes 48:1308-1315

Henle T (2008) Maillard reaction of proteins and advanced glycation end products (AGEs) in food. In: Stadler RH, Lineback DR (eds) Process-induced food toxicants. Wiley, New Jersey, pp 215-242

Ho SC, Wu SP, Lin SM, Tang YL (2010) Comparison of anti-glycation capacities of several herbal infusions with that of green tea. Food Chem 122:768-774

Hofmann SM, Dong HJ, Li Z, Cai W, Altomonte J, Thung SN, Zeng F, Fisher EA, Vlassara H (2002) Improved insulin sensitivity is associated with restricted intake of dietary glycoxidation products in the $\mathrm{db} / \mathrm{db}$ mouse. Diabetes 51:2082-2089

Howard EW, Benton R, Ahern-Moore J, Tomasek JJ (1996) Cellular contraction of collagen lattices is inhibited by nonenzymatic glycation. Exp Cell Res 228:132-137

Hsieh CL, Lin YC, Ko WS, Peng CH, Huang CN, Peng RY (2005) Inhibitory effect of some selected nutraceutic herbs on LDL glycation induced by glucose and glyoxal. J Ethn 102:357-363

Ikeda K, Higashi T, Sano H, Jinnouchi Y, Yoshida M, Araki T et al (1996) $\mathrm{N}$ (epsilon) -(carboxymethyl) lysine protein adduct is a major immunological epitope in proteins modified with advanced glycation end products of the maillard reaction. Biochem 35:8075-8083

Jakus V, Hrnciarova M, Carsky J, Krahulec B, Rietbrock N (1999) Inhibition of nonenzymatic protein glycation and lipid peroxidation by drugs with antioxidant activity. Life Sci 65:1991-1993

Janzowski C, Glaab V, Samimi E, Schlatter J, Eisenbrand G (2000) 5Hydroxymethylfurfural: assessment of mutagenicity, DNAdamaging potential and reactivity towards cellular glutathione. Food Chem Toxicol 38:801-809 
John WG, Lamb EJ (1993) The maillard or browning reaction in diabetes. Eye 7:230-237

Keita Y, Michailova M, Kratzer W, Worner G, Worner W, Rietbrock N (1992) Influence of penicillamine on the formation of early nonenzymatic glycation products of human serum proteins. Int $\mathrm{J}$ Clin Pharmacol Ther Toxicol 30:441-442

Khalifah RG, Baynes JW, Hudson BG (1999) Amadorins: novel postamadori inhibitors of advanced glycation reactions. Biochem Biophys Res Commun 257:251-258

Klopotek Y, Otto K, Bohm V (2005) Processing strawberries to different products alters contents of vitamin $\mathrm{C}$, total phenolics, total anthocyanins, and antioxidant capacity. J Agric Food Chem 53:5640-5646

Koschinsky T, He CJ, Mitsuhashi T, Bucala R, Liu C, Buenting C, Heitmann K, Vlassara H (1997) Orally absorbed reactive glycation products (glycotoxins): an environmental risk factor in diabetic nephropathy. Proc Natl Acad Sci U S A 94(12):6474-6479

Kume S, Kato S, Yamagishi S, Inagaki Y, Ueda S, Arima N, Okawa T, Kojiro M, Nagata K (2005) Advanced glycation End-products attenuate human mesenchymal stem cells and prevent cognate differentiation into adipose tissue, cartilage and bone. J Bone Mineral Res 20(9):1647-1658

Lander HM, Taurus JM, Ogiste JS, Hori O, Moss RA, Schmidt AM (1997) Activation for the receptor for AGE triggers a p21 rats dependent mitogen activated protein kinase pathway regulated by oxidant stress. J Biol Chem 272:17810-17814

Ledl F, Schleicher E (1990) New aspects of the maillard reaction in foods and in the human body. Angew Chem Int Ed 29:565-594

Lee GY, Jang DS, Lee YM, Kim JM, Kim JS (2006) Naphthopyrone glucosides from the seeds of cassia tora with inhibitory activity on advanced glycation end products (AGEs) formation. Arch Pharm Res 29:587-590

Liang CP, Wang M, Simon JE, Ho CT (2004) Antioxidant activity of plant extracts on the inhibition of citral off-odor formation. Mol Nutr Food Res 48:308-317

Lin RY, Choudhury RP, Cai W, Lu M, Fallon JT, Fisher EA, Vlassara H (2003) Dietary glycotoxins promote diabetic atherosclerosis in apolipoprotein E-deficient mice. Atherosclerosis 168:213-220

Lo CY, Li S, Tan D, Pan MH, Sang S, Ho CT (2006) Trapping reactions of reactive carbonyl species with tea polyphenols in simulated physiological conditions. Mol Nutr Food Res 50(12):1118-1128

Makita Z, Vlassara H, Cerami A, Bucala R (1992) Immunochemical detection of advanced glycosylation end products in vivo. J Biol Chem 267:5133-5138

Makita Z, Yunagisawa K, Kawajima S, Bucala R, Vlassara H, Koike T (1996) The role of advanced glycation end products in the pathogenesis of atherosclerosis. Nephrol Dial Transplant 11(Suppl 5):3133

Malik NS, Meek KM (1994) The inhibition of sugar-induced structural alterations in collagen by aspirin and other compounds. Biochem Biophys Res Commun 99:683-686

Meerwaldt R, Links T, Graaff R, Thorpe SR, Baynes JW, Hartog J, Gans R, Smit A (2005) Simple noninvasive measurement of skin autofluorescence. Ann N Y Acad Sci 1043:290-298

Metz TO, Alderson NL, Thorpe SR, Baynes JW (2003) Pyridoxamine, an inhibitor of advanced glycation and lipoxidation reactions: a novel therapy for treatment of diabetic complications. Arch Biochem Biophys 419:41-49

Miyata T, Ueda Y, Horie K, Nangaku M, Tanaka S, van Ypersele DS, Kurokawa K (1998) Renal cataboloism of advanced glycation end products: the fate of pentosidine. Kidney Int 53:416-422

Miyata T, van Ypersele de Strihou C, Kurakawa K, Baynes JW (1999) Alteration in non-enzymatic biochemistry in uraemia: origin and significance of "carbonyl stress" in long term uraemic complications. Kidney Int 55:389-399
Nakagawa T, Yokozawa T, Terasawa K, Shu S, Juneja LR (2002) Protective activity of green tea against free radical- and glucosemediated protein damage. J Agric Food Chem 50:2418-2422

Nicholl ID, Bucala R (1998) AGE and cigarette smoking. Cell Mol Biol 44:1025-1033

Nursten H ( 2005a) Introduction. In: The Maillard Reaction Chemistry, Biochemistry and Implications. The Royal Society of Chemistry, pp $1-4$

Nursten H (2005b) Recent advances. In: The Maillard Reaction Chemistry, Biochemistry and implications. The Royal Society of Chemistry, pp 31-51

O'Brien J, Morrissey PA (1989) Nutritional and toxicological aspects of the maillard browning reaction in foods. Crit Rev Food Sci Nutr 28: 211-248

Peculis R, Konrade I, Skapare E, Fridmanis D, Nikitina-Zake L, Lejnieks A, Pirags V, Dambrova M, Klovins J (2013) Identification of glyoxalase 1 polymorphisms associated with enzyme activity. Gene 515:140-143

Peng X, Cheng KW, Ma J, Chen B, Ho CT, Lo C et al (2008a) Cinnamon bark proanthocyanidins as reactive carbonyl scavengers to prevent the formation of advanced glycation endproducts. J Agric Food Chem 56:1907-1911

Peng X, Zheng Z, Cheng KW, Shan F, Ren GX, Chen F, Wang M (2008b) Inhibitory effect of mung bean extract and its constituents vitexin and isovitexin on the formation of advanced glycation endproducts. Food Chem 106:475-481

Peng X, Ma J, Cheng KW, Jiang Y, Chen F, Wang M (2010) The effects of grape seed extract fortification on the antioxidant activity and quality attributes of bread. Food Chem 119:49-53

Peppa MC, He C, Hattori M et al (2003a) Fetal or neonatal lowglycotoxin environment prevents autoimmune diabetes in NOD mice. Diabetes 52:1441-1448

Peppa M, Brem H, Ehrlich P, Zhang JG, Cai W, Li Z, Croitoru A, Thung S, Vlassara H (2003b) Adverse effects of dietary glycotoxins on wound healing in genetically diabetic mice. Diabetes 52:2805-2813

Perez-Locas C, Yaylayan VA (2010) The Maillard reaction and food quality deterioration. In: Skibsted LH, Risbo J, Andersen ML (eds) Chemical deterioration and physical instability of food and beverages. Woodhead Publishing, Cambridge, pp 70-94

Pouillart P, Mauprivez H, Ait-Ameur L, Cayzeele A, Lecerf JM, Tessier FJ, Birlouez-Aragon I (2008) Strategy for the study of the health impact of dietary maillard products in clinical studies - the example of the ICARE clinical study on healthy adults. Ann N Y Acad Sci 1126:173-176

Poulsen MW, Hedegaard RV, Anderson JM, Courten B, Bugel S, Nielsen J, Skibsted LH, Dragsted L (2013) Advanced glycation endproducts in food and their effects on health. Food Chem Toxicol. doi:10.1016/ j.fct.2013.06.052

Rabbani N, Thornalley PJ (2012) Methylglyoxal, glyoxalase 1 and the dicarbonyl proteome. Amino Acids 42:1133-1142

Rahbar S, Figarola J (2002) Inhibitors and breakers of advanced glycation endproducts (AGEs): a review. Current medicinal chemistry - immunology. Endocrine \& Metabolic Agents 2:135-161

Rahbar S, Blumenfe O, Ranney HM (1969) Studies of an unusual hemoglobin in patients with diabetes mellitus. Biochem Biophys Res Commun 36:838-843

Raj DS, Choudhury D, Welbourne TC, Levi M (2000) AGE: a nephrologist's perspective. Am J Kidney Dis 35:365-380

Rufian-Henares JA, Guerra-Henandez E, Garcia-Villanova B (2004) Pyralline content in enteral formula processing and storage and model systems. Eur Food Res Technol 219:42-47

Rutter K, Sell DR, Fraser N, Obrenovich M, Zito M, Starke-Reed P et al (2003) Green tea extract suppresses the age-related increase in collagen crosslinking and fluorescent products in C57BL/6 mice. Int J Vitam Nutr Res 73(6):453-460 
Sano H, Higashi T, Matsumoto K et al (1998) Insulin enhances macrophage scavenger receptor mediated endocytic uptake of advanced glycated end products. J Biol Chem 273:8630-8637

Schmidt AM, Hori O, Brett J, Yan SD, Wautier J, Stern D (1994) Cellular receptors for AGE's implication for induction of oxidant stress and cellular dysfunction in the pathogenesis of vascular lesions. Arterioscler Thromb 14:1521-1528

Schmidt AM, Hori O, Chen JX, Li JF, Crandall J, Zhang J, Cao R, Yan SD, Brett J, Stern D (1995) Advanced glycation end products interacting with their endothelial receptor induce expression of vascular cell adhesion molecule-1 (VCAM-1) in cultured human endothelial cells and in mice: a potential mechanism for the accelerated vasculopathy of diabetes. J Clin Invest 96:1395-1403

Schmidt AM, Hori O, Cao R et al (1996) RAGE a novel receptor for AGE's. Diabetes 45(Suppl 3):S77-S80

Schmidt AM, Yan SD, Wautier J-L, Stern D (1999) activation of receptor for advanced glycation end-products: a mechanism for chronic vascular dysfunction in diabetic vasculopathy and atherosclerosis. Circ Res 84:489-497

Sebekova K, Faist V, Hofmann T, Schinzel R, Heidland A (2003) Effects of a diet rich in advanced glycation end products in the rat remnant kidney model. Am J Kidney Dis 41:48-51

Sebekova K, Saavedra G, Zumpe C, Somoza V, Klenovicsova K, Birlouez-Aragon I (2008) Plasma concentration and urinary excretion of Ne-(carboxymethyl)lysine in breast milk- and formula-fed infants. Ann N Y Acad Sci 1126:177-180

Seiquer I, Diaz-Alguacil J, Delgado-Andrade C, Lopez-Frias M, Munoz HA, Galdo G, Navarro MP (2006) Diets rich in maillard reaction products affect protein digestibility in adolescent males aged 11-14 y. Am J Clin Nutr 83:1082-1088

Shangari N, Depeint F, Furrer R, Bruce WR, O'Brien PJ (2005) The effects of partial thiamin deficiency and oxidative stress (i.e., glyoxal and methylglyoxal) on the levels of alpha-oxoaldehyde plasma protein adducts in Fischer 344 rats. FEBS Lett 579:5596-5602

Skog KI, Johansson MA, Jagerstad MI (1998) Carcinogenic heterocyclic amines in model systems and cooked foods: a review on formation, occurrence and intake. Food Chem Toxicol 36:879-896

Skovsted IC, Christensen M, Breinholt J (1998) Characterisation of a novel age-compound derived from lysine and 3-deoxyglucasone. Cell Mol Biol 44:1159-1163

Smit AJ, Lutgers HL (2004) The clinical relevance of advanced glycation endproducts (AGE) and recent developments in pharmaceutics to reduce AGE accumulation. Curr Med Chem 11:2767-2784

Somoza V, Wenzel E, Weiss C, Clawin-Radecker I, Grubel N, Erbersdobler HF (2006) Dose-dependent utilisation of caseinlinked lysinoalanine, N(epsilon)-fructoselysine and N(epsilon)carboxymethyllysine in rats. Mol Nutr Food Res 50:833-841

Stitt AW, Bucala R, Vlassara H (1997a) Atherogenesis and advanced glycation: promotion, progression and prevention. Ann NY Acad Sci 811:115-129

Stitt AW, Li YM, Gardiner TA, Bucala R, Archer DB, Vlassara H (1997b) Advanced glycated end-products (AGE) co-localise with AGE receptors in the retinal vasculature of diabetic and AGE infused rats. Am J Pathol 150:523-539

Story M, Hayes M, Kalina B (1996) Availability of foods in high schools: is there cause for concern? J Am Diet Assoc 96:123-126

Suzuki D, Miyata T, Saotome N, Horie K, Inagi R, Ysauda Y, Uchida K, Izuhara Y, Yagame M, Sakai H, Kurokawa K (1999) Immunohistochemical evidence for an increased oxidative stress and carbonyl modification in protein in diabetic glomerular lesions. J Am Soc Nephrol 10:822-832

Tan AL, Sourris KC, Harcourt BE, Thallas-Bonke V, Penfold S, Andrikopoulos S, Thomas MC, O’Brien RC, Bierhaus A, Cooper ME, Forbes JM, Coughlan MT (2010) Disparate effects on renal and oxidative parameters following RAGE deletion, AGE accumulation inhibition, or dietary AGE control in experimental diabetic nephropathy. Am J Physiol Ren Physiol 298:763-770

Tareke E, Rydberg P, Karlsson P, Eriksson S, Tornqvist M (2002) Analysis of acrylamide, a carcinogen formed in heated foodstuffs. J Agric Food Chem 50:4998-5006

Thornalley PJ (1996) Pharmacology of methylglyoxal. Gen Pharmacol 27:565-573

Thornalley PJ (1998) Cell activation by glycated proteins. AGE receptors, receptor recognition factors and functional classification of AGEs. Cell Mol Biol 44:1013-1023

Thornalley PJ, Westwood M, Lo TW, McLellan AC (1995) Formation of methylglyoxal - modified proteins in vitro and in vivo and their involvement in AGE - related processes. Contrib Nephrol 112:24 31

Thornalley PJ, Lang borg A, Minhas HS (1999) Formation of glyoxal, methylglyoxal and 3-DG in the glycation of proteins. Biochem $\mathrm{J}$ 344:109-116

Ulrich P, Cerami A (2001) Protein glycation, diabetes and aging. Recent Prog Horm Res 56:21

Uribarri J. (2012) Advanced Glycation End Products. In: Daugirdas JT. (ed) handbook of chronic kidney disease management. Lippincott Willliams and Wilkins, pp 152-158

Uribarri J, Peppa M, Cai W, Goldberg Tet al (2003) Restriction of dietary glycotoxins markedly reduces AGE toxins in renal failure patients. J Am Soc Nephrol 14:728-731

Uribarri J, Cai WJ, Sandu O, Peppa M, Goldberg T, Vlassara H (2005) Diet- derived advanced glycation end products are major contributors to the body's AGE pool and induce inflammation in healthy subjects. Ann N Y Acad Sci 1043:461-466

Uribarri J, Cai W, Peppa M, Goodman S, Ferruci L, Striker G, Vlassara H (2007) Circulating glycotoxins and dietary advanced glycation endproducts: Two links to inflammatory response oxidative stress, and aging. J Gerontol A Biol Sci Med Sci 62:427-433

Uribarri J, Woodruff S, Goodman S, Cai W, Chen X, Pyzik R, Yong A, Striker GE, Vlassara H (2010) Advanced glycation end products in foods and a practical guide to their reduction in the diet. J Am Diet Assoc 110(6):911-16

Vashishth D, Gibson GJ, Khoury JI, Schaffler MB, Kimura J, Fy hrie DP (2001) Influence of nonenzymatic glycation on biomechanical properties of cortical bone. Bone 28:195-201

Verzijl N, Bank RA, TeKoppele JM, DeGroot J (2003) AGEing and osteoarthritis: a different perspective. Curr Opin Rheumatol 15: 616-622

Vikram VB, Ramesh MN, Prapulla SG (2005) Thermal degradation kinetics of nutrients in orange juice heated by electromagnetic and conventional methods. J Food Eng 69:31-40

Vlassara H (2001) The AGE-receptor in the pathogenesis of diabetic complications. Diabetes Metab Rev 17:436-443

Vlassara H, Bucala R (1996) Recent progress in advanced glycation and diabetic vascular disease: role of AGE receptors. Diabetes 45(Suppl 3):65-66

Vlassara H, Uribarri J (2004) Glycoxidation and diabetic complications: modern lessons and a warning? Rev Endocr Metab Disord 5:181188

Vlassara H, Cai W, Crandall J, Goldberg T, Oberstein R, Dardaine V, Peppa M, Rayfield EJ (2002) Inflammatory mediators are induced by dietary glycotoxins: a major risk factor for diabetic angiopathy. Proc Natl Acad Sci U S A 99:15596-15601

Voziyan PA, Metz TO, Baynes JW, Hudson BG (2002) A post-Amadori inhibitor pyridoxamine also inhibits chemical modification of proteins by scavenging carbonyl intermediates of carbohydrate and lipid degradation. J Biol Chem 277:3397-3403

Wu LY, Juan CC, Ho LT, Hsu YP, Hwang LS (2004) Effect of green tea supplement on insulin sensitivity in Sprague-Dawley rats. J Agric Food Chem 52:643-648 
Wu JC, Li XH, Peng YD, Wang JB, Tang JF, Wang YF (2011) Association of two glyoxalase I gene polymorphisms with nephropathy and retinopathy in type 2 diabetes. J Endocrinol Investig. doi: $10.3275 / 7856$

Xue M, Rabbani N, Momiji H, Imbasi P, Anwar MM, Kitteringham N, Park BK, Souma T, Moriguchi T, Yamamoto M, Thornalley PJ (2012) Transcriptional control of glyoxalase 1 by Nrf2 provides a stress-responsive defence against dicarbonyl glycation. Biochem J 443:213-222

Yaacoub R, Saliba R, Nsouli B, Khalaf G, Birlouez-Aragon I (2008) Formation of lipid oxidation and isomerization products during processing of nuts and sesame seeds. Journal Agric Food Chem 6:7082-7090

Yamaguchi F, Ariga T, Yoshimura Y, Nakazawa H (2000) Antioxidative and anti-glycation activity of garcinol from garcinia indica fruit rind. J Agric Food Chem 48:180-185
Yokozawa T, Nakagawa T (2004) Inhibitory effects of Luobuma tea and its components against glucose-mediated protein damage. Food Chem Toxicol 42:975-981

Zhang Q, Ames JM, Smith RD, Baynes JW, Metz TO (2009) A perspective on the maillard reaction and the analysis of protein glycation by mass spectrometry: probing the pathogenesis of chronic disease. $\mathrm{J}$ Proteome Res 8:754-769

Zheng F, He C, Cai W, Hattori M, Steffes M, Vlassara H (2002) Prevention of diabetic nephropathy in mice by a diet low in glycoxidation products. Diabetes Metab Res Rev 18:224-237

Zieman S, Kass D (2004) Advanced glycation end product cross-linking: pathophysiologic role and therapeutic target in cardiovascular disease. Congest Heart Fail 10:144-149 